\title{
Quantification of Venturia inaequalis Growth in Malus × domestica with Quantitative Real-Time Polymerase Chain Reaction
}

Michele Gusberti, Institute of Integrative Biology Zurich, Plant Pathology Group, Swiss Federal Institute of Technology, CH-8092 Zürich, Switzerland; Andrea Patocchi, Agroscope Changins Wädenswil ACW Research Station, Schloss, CH-8820 Wädenswil, Switzerland; and Cesare Gessler and Giovanni A. L. Broggini, Institute of Integrative Biology Zurich, Plant Pathology Group, Swiss Federal Institute of Technology, CH-8092 Zürich, Switzerland

\begin{abstract}
Gusberti, M., Patocchi, A., Gessler, C., and Broggini, G. A. L. 2012. Quantification of Venturia inaequalis growth in Malus $\times$ domestica with quantitative real-time polymerase chain reaction. Plant Dis. 96:1791-1797.

A quantitative real-time polymerase chain reaction (qPCR) was developed and validated for quantification of Venturia inaequalis in infected leaf tissue of Malus $\times$ domestica. The method is based on dual-labeled hybridization probes, allowing simultaneous detection of host and pathogen DNA within one single reaction. Limit of quantification for the pathogen was $0.5 \mathrm{pg}$ per reaction and, for the host, reached $5 \mathrm{pg}$ per reaction. The fungal growth measured in four apple cultivars 2 weeks after inoculation significantly correlated with their different level of scab resistance and allowed the observation of ontogenic resistance. After sporulation on the youngest leaf, fungal biomass in susceptible

'Gala' was 118 times higher than in resistant 'Florina' and 'Discovery' while intermediate values were found with the intermediate susceptible 'Milwa'. Correlation was also observed between severity classes obtained by visual scoring of symptoms and qPCR results. Moreover, qPCR demonstrated validity of the developed method as a disease severity forecast tool 10 days after the pathogen's inoculation and prior to the appearance of the symptoms. Applications of the methodology can include the quantification of scab resistance during breeding programs, evaluation of fungicide and biocontrol efficacy, and quantification of the fitness of different pathogenic strains.
\end{abstract}

Apple (Malus $\times$ domestica Borkh.) is one of the most widely cultivated fruit crops in regions with temperate climates. One of the major constraints of apple cultivation is apple scab, the fungal disease caused by Venturia inaequalis (Cooke) G. Winter. The disease can lead to severe crop losses if not properly controlled (19).

Disease control can be achieved by fungicide applications (26), field sanitation (17), and resistant cultivars $(13,15)$. Breeding for scab resistance is one of the most important tasks today to decrease chemical pesticides in the environment, thus decreasing the risk of health problems to both the consumer and the farmer as well as of the development of fungicide resistance. Breeding programs generate thousands of seedlings that need to be screened carefully for apple scab resistance.

When breeding for scab resistance associated to major genes, a scale based on type of symptoms is overwhelmingly used (11). This scale can be associated with quantitative measures (38). Qualitative scales (e.g., Croxall et al. [12] or Croxall-modified scale [30]) are occasionally used to asses apple scab severity at the plant level. In both cases, the amount of the pathogen present is only inferred rather than measured. However, epidemiologically important differences associated with such factors as the rapidity of lesion expansion cannot be detected through this type of assessment. Furthermore, visual assessment of scab lesions in the field is sometimes confounded by misidentification of the pathogen. Differences in lesion development rate associated with leaf age $(20,36)$ may be overlooked. Similarly, scab lesions that remain latent or develop slowly due to inhibition by fungicides may be missed by visual scoring, leading to incorrect decisions. Leaves in the rosette stage may have microscopically observable scab infections that would be overlooked by visual scoring (23) but can

Corresponding author: C. Gessler, E-mail: cesare.gessler@usys.ethz.ch

Accepted for publication 5 July 2012.

http://dx.doi.org/10.1094/PDIS-12-11-1058-RE

(C) 2012 The American Phytopathological Society sporulate as soon as the ontogenic resistance disappears late in the season (22). Moreover, an apparently healthy tissue may serve as overwintering site, producing ascospores for primary infections in the following spring (23).

Another limitation of visual scoring is its subjectivity; for example, different screeners could place the same sample in different symptom severity classes. A molecular method could be useful to quantify pathogens, allowing a better understanding of the growth dynamics of the fungus.

Molecular quantification of pathogens in living tissues has become a widely used method in disease diagnostics (18). The first report of the use of real-time polymerase chain reaction (PCR) in plant pathology was published more than a decade ago (3). Since then, many real-time PCR based methods have been developed (35).

The methodology chosen in this study to quantify $V$. inaequalis in Malus $\times$ domestica in artificially inoculated leaves is based on real-time quantitative (q)PCR. This method makes it possible to quantify both host and pathogen DNA in the same sample, allowing quantification of pathogen growth in host tissues $(28,42)$. In contrast to conventional visual scoring, DNA-based methods have the advantages of species specificity, sensitivity, speed, and potential for automation.

The objectives of the present work were the development and validation of a TaqMan-based qPCR for the quantification of $V$. inaequalis growth in artificially infected apple leaves by comparing (i) visual scoring with molecular data, (ii) relative fungal growth in different cultivars, (iii) between different fungal isolates, (iv) in different aged leaves, and (v) in apple breeding material such as segregating populations.

\section{Materials and Methods}

Plant material. One-year-old apple (Malus $\times$ domestica Borkh.) saplings ('Gala', 'Milwa', 'Discovery', and 'Florina' grafted on M9T337 rootstock) in 4.8-liter pots that had two to three shoots with $8 \pm 2$ leaves each were chosen for the experiments. Seedlings $\left(F_{1}\right)$ from the cross 'Gala $\times$ Dülmener Rosenapfel' $(n=41)$ and 1year-old seedlings on their own roots of the cross 'Gala $\times$ Durello di Forlì' $(n=60)$ were also used. Gala was considered the most 
susceptible cultivar, carrying no major resistance genes (31), whereas Milwa and Discovery (with minor and probably Rvil resistance genes; 8) were considered intermediate (21) and Florina resistant, carrying the Rvi6 and Rvil scab resistance genes. 'Dülmener Rosenapfel' carries the Rvil4 resistance gene and three quantitative traits loci (37), whereas 'Durello di Forlì' carries only the Rvil3 resistance gene (38). For a review of major resistance genes present in apple, see Bus et al. (5).

Leaves were numbered from the top of the shoot toward the base; leaf one was the youngest unfurled and expanding leaf and leaves three and five corresponded to the third and fifth leaf positions, respectively. Leaf unfolding rate was estimated in one leaf emerging every 2 to 2.5 days $(24,41)$ under the used climatic conditions; thus, the difference in age between the chosen leaves was approximately 4 to 5 days.

Inoculum and inoculation procedure. Conidia of $V$. inaequalis were obtained from either leaves with sporulating lesions previously inoculated with single-spore isolates EU-NL24 and 1066 $(2,29)$ or sporulating leaves collected on apple seedlings at the Swiss Federal Research Station Agroscope Wädenswil. Briefly, sporulating leaves were vortexed in tap water and conidia concentration was quantified under a microscope using a hemocytometer and adjusted using tap water. Inoculations were performed by wetting leaves with a hand sprayer using a conidia suspension $\left(10^{5}\right.$ or $5 \times 10^{5}$ conidia $\left.\mathrm{ml}^{-1}\right)$ at $15^{\circ} \mathrm{C}$ and approximately $100 \%$ relative humidity $(\mathrm{RH})$ in the dark. After a 48 -h incubation period, plants were moved back to their previous locations in the greenhouse and maintained at $22 \pm 2{ }^{\circ} \mathrm{C}, 60 \pm 10 \% \mathrm{RH}$, a photoperiod of 16 and $8 \mathrm{~h}$ (day and night, respectively), and a minimum of 183.3 $\mu \mathrm{mol} \mathrm{m} \mathrm{m}^{-2} \mathrm{~s}^{-1}$ light intensity. Seedlings of Gala $\times$ Dülmener Rosenapfel were chamber inoculated using $150 \mu \mathrm{l}$ of the isolates EU-NL24 and 1066, each isolate used alone in two different places on the leaf, at a concentration of $10^{5}$ conidia $\mathrm{ml}^{-1}$ following the inoculation procedure with chambers (chamber done with microtube lids glued onto hair clips), as described in a previous study (4), giving an inoculation area of approximately $1 \mathrm{~cm}^{2}$ for each single-spore isolate.

DNA extraction. DNA was extracted manually from entire apple leaves using the cetyltrimethylammonium bromide (CTAB) method (1), with minor modifications: tissues were freeze dried with 5 to $102-\mathrm{mm}$ glass beads and ground with the FP 120 FastPrep machine (Bio 101 Savant Instruments Inc.; Qbiogene) for $30 \mathrm{~s}$ at a speed of $5.5 \mathrm{~m} \mathrm{~s}^{-1}$. Samples were incubated for $1 \mathrm{~h}$ at $65^{\circ} \mathrm{C}$ with $1.2 \mathrm{ml}$ of extraction buffer $(2 \% \mathrm{CTAB} ; 2 \%$ polyvinylpyrrolidone [K30]; $1.4 \mathrm{M} \mathrm{NaCl} ; 20 \mathrm{mM}$ EDTA, $\mathrm{pH}=8$; and $100 \mathrm{mM}$ Tris $\mathrm{HCl}, \mathrm{pH}=8)$ and $5 \mu \mathrm{l}$ of RNase $\left(10 \mathrm{mg} \mathrm{ml}^{-1}\right)$. Eppendorf tubes $(2$ $\mathrm{ml}$ each) were centrifuged for $10 \mathrm{~min}$ to remove nonsoluble debris. Samples were then mixed for $30 \mathrm{~min}$ at room temperature (RT) with $800 \mu \mathrm{l}$ of phenol/chloroform/isoamyl alcohol (25:24:1; Sigma-Aldrich). After 10 min of centrifugation, the aqueous phase was transferred to a new tube with $800 \mu \mathrm{l}$ of cold isopropanol $\left(-20^{\circ} \mathrm{C}\right)$ and incubated for $10 \mathrm{~min}$ at RT to precipitate DNA. After 10 min of centrifugation and isopropanol discharge, samples were washed twice with $500 \mu \mathrm{l}$ of $70 \% \mathrm{EtOH}\left(-20^{\circ} \mathrm{C}\right)$ and 5 min of centrifugation after each wash. The DNA pellet was suspended in $100 \mu \mathrm{l}$ of sterile distilled water. Centrifugations were always performed at 13,200 rpm on a 5415D Centrifuge (Eppendorf).

Depending on the leaf area, the DNA extractions of infected leaves were performed in batches ( 1 to 4$)$, then pooled together, and DNA was allowed to precipitate for $20 \mathrm{~min}$ at $-20^{\circ} \mathrm{C}$ with $1 / 10$ vol of $3 \mathrm{M}$ sodium acetate and 2 vol of $100 \% \mathrm{EtOH}\left(-20^{\circ} \mathrm{C}\right)$. Resuspension of the air-dried pellets was done in $100 \mu \mathrm{l}$ of sterile distilled water after two rinses with $70 \% \mathrm{EtOH}$ and $5 \mathrm{~min}$ of centrifugation. DNA extracted from infected leaves was used undiluted, whereas the amount of DNA extracted used for the standard curve, calibration DNA, and qPCR optimization (see below) was quantified with a NanoDrop ND-1000 spectrophotometer (NanoDrop Technology) and diluted to the desired concentration.

Real-time qPCR assay. Primers and TaqMan probes: design and specificity test. V. inaequalis and Malus $\times$ domestica primers and probes (Table 1) were designed using the Primer3 online software (http://primer3.sourceforge.net) (34) on the housekeeping genes sequences ATP-binding cassette transporter 2 (ABC2) for $V$. inaequalis (accession number AF227915.2) and elongation factor $1 \alpha$ (EF1) for Malus $\times$ domestica (accession number DQ341381.1). Sequences were checked for homologies using the National Center for Biotechnology Information BLAST.

Primer specificity for ABC2 was tested with end-point PCR over 23 field ascosporic lesions collected in 2001 in North America (3 from Minnesota, 4 from Michigan, 2 from Maine, 5 from New York, and 9 from New Hampshire; G. Valsesia and C. Gessler, unpublished) and 14 single-spore isolate from Europe (3 from France, 3 from Germany, 3 from North Italy, 3 from Netherland, and 2 from Switzerland), described in earlier works $(39,40)$. Moreover, $\mathrm{ABC} 2$ primers were tested with four single-spore isolates (i.e., 1066, EU-B04, EU-NL24, and 1639) previously described $(2,4,6,29)$ and with greenhouse-inoculated apple leaves. Primer and probe specificity tests for EF1 and ABC2 were performed with qPCR by testing DNA extracted from 10 fieldcollected asymptomatic leaves, 10 greenhouse-inoculated and not inoculated leaves, the 23 ascosporic lesions collected in North America, and 18 single-spore isolates collected in Europe.

Conventional end-point PCR was performed with $\mathrm{ABC} 2$ and EF1 primers pairs (Table 1 ) in a $20-\mu$ reaction, composed of $1 \times$ PCR buffer (Fermentas), $0.1 \mathrm{mM}$ dNTPs, $0.1 \mu \mathrm{M}$ ABC2, $0.05 \mu \mathrm{M}$ EF1 primer pairs, DreamTaq DNA polymerase (Fermentas) at 0.07 $\mathrm{U} \mu \mathrm{l}^{-1}$, and $5 \mu \mathrm{l}$ of DNA $\left(1 \mathrm{ng} \mu^{-1}\right)$. PCR thermocycler conditions were 3 min at $94^{\circ} \mathrm{C}$ (initialization) followed by 40 cycles of $94^{\circ} \mathrm{C}$ for $30 \mathrm{~s}$ (denaturing), $55^{\circ} \mathrm{C}$ for $15 \mathrm{~s}$ (annealing), and $72^{\circ} \mathrm{C}$ for $15 \mathrm{~s}$ (elongation). The PCR products were then loaded on $2.5 \%$ (wt/vol) agarose gel in $0.5 \times$ Tris-Borate-EDTA (TBE) buffer at $125 \mathrm{~V}$ for $2 \mathrm{~h}$.

Real-time $q P C R$ protocol. Real-time $\mathrm{qPCR}$ was performed on the ABI's 7500 Fast Real-Time Sequences Detection System (Applied Biosystems) and analyzed with the Sequence Detection Software (v. 1.4; Applied Biosystems). Amplification conditions were $20 \mathrm{~s}$ at $95^{\circ} \mathrm{C}$ followed by 50 cycles of $3 \mathrm{~s}$ at $95^{\circ} \mathrm{C}$ (denaturing) and

Table 1. Real-time quantitative polymerase chain reaction primers and probes used for the quantification of Venturia inaequalis in Malus $\times$ domestica tissues

\begin{tabular}{|c|c|c|c|c|}
\hline Organism, number, name ${ }^{w}$ & {$[\mathbf{x}](\mathbf{n M})^{\mathrm{x}}$} & Sequences $\left(5^{\prime}-3^{\prime}\right)$ & Dyes $^{y}$ & Product size $(b p)^{z}$ \\
\hline \multicolumn{5}{|c|}{ Venturia inaequalis, AF227915.2 } \\
\hline $\mathrm{ABC} 2_{\mathrm{F}}$ & 900 & GCATTGTCATCGCCATTGTT & - & $\ldots$ \\
\hline $\mathrm{ABC} 2_{\mathrm{R}}$ & 900 & GAGCACACCTCCACGAGTGA & - & $\ldots$ \\
\hline $\mathrm{ABC} 2 \mathrm{p}$ & 250 & CGATATCCCCACCAGCAGCGCA & $5^{\prime} \mathrm{YY} 3^{\prime} \mathrm{BHQ}$ & 86 \\
\hline \multicolumn{5}{|l|}{ Malus $\times$ domestica, DQ341381.1 } \\
\hline $\mathrm{EF} 1_{\mathrm{F}}$ & 600 & GAGCGTGGTATCACCATCGA & - & $\ldots$ \\
\hline $\mathrm{EF} 1_{\mathrm{R}}$ & 600 & ACAGTCAGCCTGTGATGTTCCA & - & $\ldots$ \\
\hline$E F 1_{P}$ & 400 & CGGTCATTGATGCTCCAGGGCA & $5^{\prime} \mathrm{FAM} 3^{\prime} \mathrm{BHQ}$ & 132 \\
\hline
\end{tabular}

${ }^{\mathrm{w}}$ Organism name, accession number (National Center for Biotechnology Information), and primer and probe names. ABC2 = ATP-binding cassette2, EF1 =

elongation factor $1, \mathrm{~F}=$ forward primer, $\mathrm{R}=$ reverse primer, and $\mathrm{P}=$ hybridization probe (TaqMan).

${ }^{x}$ Optimal concentrations for primers and probes were selected as defined by Vandemark and Barker (43).

${ }^{\mathrm{y}}$ Dyes: $\mathrm{YY}=$ Yakima Yellow, FAM = 6-carboxyfluorescein, and BHQ = Black Hole Quencher 1 (Microsynth).

${ }^{\mathrm{z}}$ Cycling condition: preheating stage of $20 \mathrm{~s}$ at $95^{\circ} \mathrm{C}$ followed by 50 cycles of $3 \mathrm{~s}$ at $95^{\circ} \mathrm{C}$ and $1 \mathrm{~min}$ at $60^{\circ} \mathrm{C}$. 
$1 \mathrm{~min}$ at $60^{\circ} \mathrm{C}$ (annealing and extension). Reaction mix (20- $\mu \mathrm{l}$ reaction), before optimization, contained $15 \mu \mathrm{l}$ of Master Mix (10 $\mu \mathrm{l}$ of TaqMan Fast Universal Master mix [Applied Biosystems], $900 \mathrm{nM}$ $\mathrm{ABC} 2$ and $\mathrm{EF} 1$ primer pairs, $250 \mathrm{nM} \mathrm{ABC} 2$ and $\mathrm{EF} 1$ probes [Microsynth AG], and $3.28 \mu \mathrm{l}$ of sterile distilled water) and $5 \mu \mathrm{l}$ of genomic DNA. Threshold line was set manually at 0.2 in every analysis. Each 96-well plate (MicroAmp fast Optical 96-Well Reaction Plate; Applied Biosystems) was loaded with no-template controls, calibration DNA, and positive controls in triplicates. Plates were sealed with MicroAmp clear adhesive film (Applied Biosystems).

Standard curves, calibration DNA, and qPCR optimization pro-

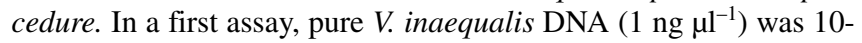
fold serially diluted in sterile distilled water. In a second assay $V$.

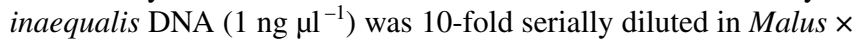
domestica 'Golden Delicious' DNA $\left(1 \mathrm{ng} \mu \mathrm{l}^{-1}\right)$ to investigate possible influence of host DNA on pathogen DNA amplification. The same dilution series (10-fold) was also generated for host DNA $\left(100 \mathrm{ng}^{-1} \mathrm{l}^{-1}\right)$ in sterile distilled water.

To evaluate whether PCR efficiencies between different aged leaves were comparable, dilution series (10-fold) of known host

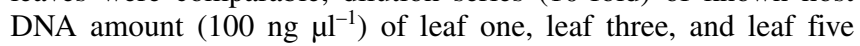
were performed. Serial dilutions were carried out in six replicates. With the DNA serial dilution, the PCR efficiency for both host and pathogen was calculated according to Rasmussen (33).

To allow comparisons between results of different tests, a calibration DNA was added in triplicate to each experiment and analyzed as a dual-species sample. The calibration DNA contained

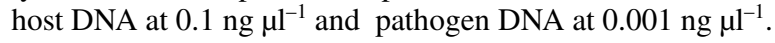

Optimization of the qPCR was performed with each primer and probe set individually, and optimal concentrations for primers and probes were selected as defined in a previous study (43). All reactions were carried out in triplicates.

Colonization coefficient. Cycle threshold $(\mathrm{Ct})$ values obtained by real-time PCR were transformed to DNA amount for both species using the linear regression obtained from the serial dilution experiment $\left(\mathrm{DNA}[\mathrm{x}]\left(\mathrm{ng} \mathrm{\mu l}^{-1}\right)=10^{[(\mathrm{Ct} \text { value }-\mathrm{y} \text {-axis intercept)/slope }]}\right.$; Table 2) (28). The colonization coefficient $\left(\mathrm{CC}_{\text {corrected }}\right)$ was calculated as the ratio between DNA concentrations of pathogen and host extracted from infected leaves and corrected, with the correction coefficient $(\triangle \mathrm{CC})$ considered as the difference in $\mathrm{CC}$ values between standard curve and calibration DNA, calculated with the following equation: $\mathrm{CC}_{\text {corrected }}=[\mathrm{x}]_{\text {DNA Venturia }} /[\mathrm{x}]_{\text {DNA Malus }}+\Delta \mathrm{CC}$.

The $\triangle \mathrm{CC}$ was calculated using a fixed $\mathrm{CC}$ value obtained from the standard curve $\left(\mathrm{CC}_{\text {stcurve }}=0.009953\right)$ and the $\mathrm{CC}$ value obtained with the calibration DNA, both containing a known amount

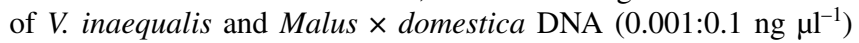
where $\Delta \mathrm{CC}=\mathrm{CC}_{\text {St.Curve }}-\mathrm{CC}_{\mathrm{DNA} \text { Cal }}=[\mathrm{x}]_{\mathrm{DNA} \text { St.Curve Venturia }} /[\mathrm{x}]_{\mathrm{DNA}}$ St.Curve Malus $-[\mathrm{x}]_{\mathrm{DNA}}$ Cal Venturia $/[\mathrm{x}]_{\mathrm{DNA}}$ Cal Malus. Consequently, $\mathrm{CC}_{\text {corrected }}=[\mathrm{x}]_{\mathrm{DNA} \text { Venturia }} /[\mathrm{x}]_{\mathrm{DNA} \text { Malus }}+\left([\mathrm{x}]_{\mathrm{DNA} \text { St.Curve Venturia }} /[\mathrm{x}]_{\mathrm{DNA}}\right.$ St.Curve Malus $\left.-[\mathrm{x}]_{\text {DNA Cal Venturia }} /[\mathrm{x}]_{\text {DNA Cal Malus }}\right)$.

The calibration DNA, averaged over three technical replicates, was used as internal reference for the normalization procedure during qPCR analysis.
Quantification by qPCR of $\mathrm{V}$. inaequalis in infected apple leaves. In order to evaluate the application potential of the developed method, several scenarios were chosen: fungal growth on different apple cultivars differing for scab resistance was followed during infection progress, quantification of ontogenic resistance of leaves, and comparison of qPCR and visual scoring of foliar disease severity 4 weeks after infection. Finally, the predictive potential of the method was assessed by comparing pathogen biomass increase after the first 10 days with the visual symptoms scored at 21 days after inoculation.

First, the method applied to quantify fungal growth was tested in four apple cultivars with different degrees of resistance to $V$. inaequalis. Three weeks after inoculation, fungal sporulation was induced by incubation at $100 \% \mathrm{RH}$ for $48 \mathrm{~h}$. During this experiment, samples of the second expanding leaf were collected 3 $\mathrm{h}$ post inoculation (hpi), 7 days post inoculation (dpi), $21 \mathrm{dpi}$, and after the sporulation treatment $(35 \mathrm{dpi})$, in triplicate. The incubation period of the pathogen was calculated by counting days between inoculation and appearance of macroscopic symptoms.

Second, the highly resistant Florina and the highly susceptible Gala were used to follow pathogen development in different aged leaves. Samples of leaf 1 , leaf 3 , and leaf 5 were collected in triplicate at 3 hpi and 4, 7, 14, and 21 dpi. We assumed that leaf 5 would exhibit ontogenic resistance whereas leaf 1 would not $(16,23,27)$.

Third, we compared colonization coefficient with the visual scoring data after symptoms development on $41 \mathrm{~F}_{1}$ seedlings of Gala $\times$ Dülmener Rosenapfel. Inoculation was done using two single-spore isolates of $V$. inaequalis ( 37 and 41 seedlings inoculated with EU-NL24 and 1066, respectively), where possible on the same leaf. Leaves were photographed 4 weeks after inoculation in order to enable visual scoring of lesions. Lesions were collected with a 2-cm-diameter leaf borer from the inoculation sites for DNA extraction and qPCR analysis.

Fourth, the colonization coefficient was calculated for samples collected $10 \mathrm{dpi}$ (before symptom development) and compared with the visual scoring data assessed $21 \mathrm{dpi}$. Before inoculation, the first expanding and actively growing leaf was marked. A conidial suspension $\left(5 \times 10^{5}\right.$ conidia $\left.\mathrm{ml}^{-1}\right)$ was used to spray inoculate 60 seedlings of an $\mathrm{F}_{1}$ progeny of Gala $\times$ Durello di Forlì. After 2 days of incubation at $15^{\circ} \mathrm{C}$ and $100 \% \mathrm{RH}$, plants were moved back to the greenhouse $\left(20 \pm 2^{\circ} \mathrm{C}\right.$ and $\left.70 \pm 10 \% \mathrm{RH}\right)$. Samples for pathogen quantification were collected using a 1-cm-diameter leaf borer on the leaf apex $10 \mathrm{dpi}$. After sample collection, plants were grown under high humidity $(70 \pm 10 \% \mathrm{RH})$ until visual scoring $21 \mathrm{dpi}$.

Data analysis. Outliers were found and removed by analyzing $\mathrm{Ct}$ values obtained with ABI's Fast 7500 Sequences Detection System (Applied Biosystems). In a preliminary experiment, we observed that apple DNA amount extracted from apple leaves of different ages was comparable $(\mathrm{Ct}=25.36 \pm 0.70 \mathrm{SD})$; therefore, samples in which apple DNA exceeded this mean were excluded. Venturia DNA, in which Ct values were higher than the quantification limit $(\mathrm{Ct}>38.32+5 \%$ standard error $)$ were excluded from the analysis.

Table 2. Standard curves generated for the quantification of Venturia inaequalis in Malus $\times$ domestica tissues

\begin{tabular}{|c|c|c|c|c|c|c|}
\hline Tested species (DNA) & $\begin{array}{l}\text { Dilution } \\
\text { material }\end{array}$ & $\begin{array}{l}\text { DNA tested } \\
\text { range }\left(\mathrm{ng} \mu \mathrm{l}^{-1}\right)^{\mathrm{v}}\end{array}$ & $\mathrm{Ct}$ values $\pm \mathrm{SD}^{\mathrm{w}}$ & Linear regression $^{x}$ & $\mathbf{E}(\%)^{\mathrm{y}}$ & $R^{2}$ \\
\hline V. inaequalis & Water & $10^{-4}$ to 1 & $38.26 \pm 1.20$ to $24.65 \pm 0.14$ & $y=-3.3929 x+24.726$ & 97.1 & 0.9998 \\
\hline V. inaequalis & Malus $\mathrm{DNA}^{\mathrm{z}}$ & $10^{-4}$ to 1 & $37.33 \pm 0.99$ to $23.81 \pm 0.07$ & $y=-3.3732 x+23.9^{\mathrm{A}}$ & 97.9 & 0.9997 \\
\hline Malus $\times$ domestica & Water & $10^{-3}$ to $10^{2}$ & $39.35 \pm 0.81$ to $22.43 \pm 0.43$ & $y=-3.3892 x+29.013^{B}$ & 97.3 & 0.9995 \\
\hline Malus $\times$ domestica leaf 1 & Water & $10^{-3}$ to $10^{2}$ & $39.05 \pm 0.46$ to $22.27 \pm 0.21$ & $y=-3.3785 x+28.916$ & 97.7 & 0.9998 \\
\hline Malus $\times$ domestica leaf 3 & Water & $10^{-3}$ to $10^{2}$ & $38.77 \pm 0.98$ to $22.11 \pm 0.05$ & $y=-3.3725 x+28.704$ & 97.9 & 0.9996 \\
\hline Malus $\times$ domestica leaf 5 & Water & $10^{-3}$ to $10^{2}$ & $39.92 \pm 1.72$ to $22.92 \pm 0.15$ & $y=-3.3743 x+29.391$ & 97.9 & 0.998 \\
\hline
\end{tabular}

${ }^{\mathrm{v}}$ Ten-fold serial dilutions generated in six replicates.

${ }^{\mathrm{w}} \mathrm{Ct}=$ threshold cycle and $\mathrm{SD}=$ standard deviation.

${ }^{\mathrm{x}}$ Linear regression obtained, plotting $\log _{10}$ DNA concentration $(x)$ on $\mathrm{Ct}$ values $(y)$, from the serial dilution experiments used for the calculation of the colonization coefficients. Formulas used in subsequent analysis for the quantification of V. inaequalis DNA (A) and Malus $\times$ domestica DNA (B).

${ }^{y}$ Polymerase chain reaction efficiency (E) calculated according to Rasmussen (33).

${ }^{\mathrm{z}}$ DNA of Malus $\times$ domestica. V. inaequalis DNA serially diluted in Malus $\times$ domestica 'Golden Delicious' DNA at $1 \mathrm{ng}^{\mu \mathrm{l}^{-1}}$. 
Where possible, we chose to isolate DNA from entire leaves instead of leaf discs to avoid inter-sample variability (42). Leaf disc sampling was used in the experiments with the $F_{1}$ progenies of Gala $\times$ Dülmener Rosenapfel and Gala $\times$ Durello di Forlì. We did not test inter-sample variability because seedlings of Gala $\times$ Dülmener Rosenapfel were inoculated using inoculation chambers and sampling point coincided with inoculation point. In the Gala $\times$ Durello di Forlì progeny, only one sample per leaf was collected in order to not further damage and stress the leaf because, at $21 \mathrm{dpi}$, a visual scoring was necessary.

No inter-assay variability was observed by comparing the colonization coefficient at different time points of leaf 1 from Gala for three biological replicates over two technical replicates; the first processed the day after DNA extraction and the second 4 months later (Fig. 1). Therefore, subsequent qPCR analyses were performed once.

Wilcoxon Rank-Sum test (two levels) and Kruskal-Wallis test (three or more levels) were used to test differences between cultivars. Differences in colonization coefficient (log transformed) within the different visual scoring classes of the $F_{1}$ progenies (Gala $\times$ Dülmener Rosenapfel and Gala $\times$ Durello di Forlì) were verified by performing the Kruskal-Wallis test and Tukey-Kramer honestly significant difference (HSD) test. All tests were carried out with a significance level $\alpha=0.05$ using JMP (version 8.0; SAS Institute Inc.) on Windows 7.

\section{Results}

Real-time qPCR assay. Primers and probes specificity test. The chosen primer pairs tested in singleplex and duplex on $2.5 \%$ (wt/vol) agarose gel in $0.5 \times \mathrm{TBE}$ buffer showed amplification products with the target DNA ( $V$. inaequalis 86 bp for ABC2 and Malus $\times$ domestica 132 bp for EF1 primers; Table 1). No amplification product using the pathogen primers was detected with DNA from uninfected leaves, and host primers did not amplify pure pathogen DNA. Primer and probe qPCR specificity tests of EF1 resulted in specific amplification of all samples containing apple DNA (23 field-collected North American ascosporic lesions, and 10 asymptomatic field-collected and 10 greenhouse asymptomatic and symptomatic apple leaves), and no amplification was found with pure pathogen DNA (18 European single-spore isolates). Primer and probe specificity tests of $\mathrm{ABC} 2$ showed specific amplification of the targeted DNA (18 single-spore isolates collected in Europe, 23 field-collected North American ascosporic lesions, and 5 greenhouse-inoculated apple leaves) and no unspecific amplification could be found in the absence of the target DNA (10 asymptomatic field-collected apple leaves and 5 noninoculated

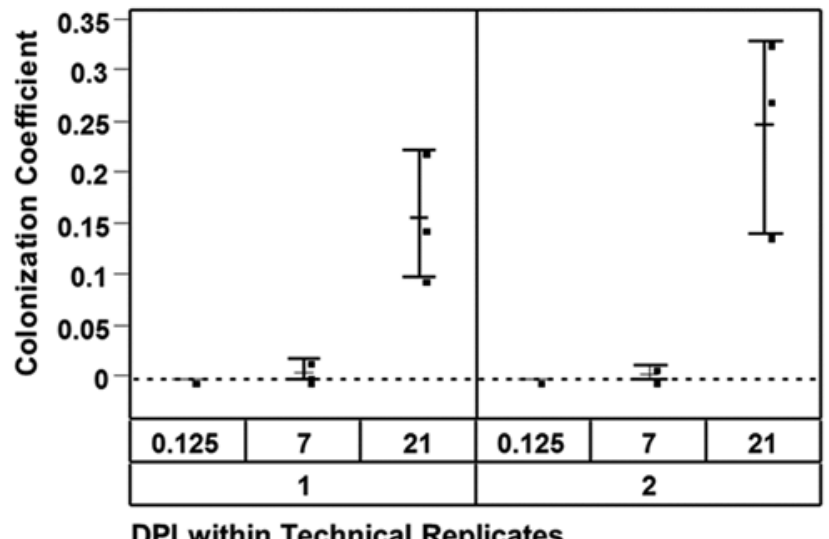

Fig. 1. Inter-assay variability test. DNA extracted from the youngest expanding leaf (L1) of 'Gala' artificially inoculated with field inoculum of Venturia inaequalis. Samples, collected at three time points ( 3 hours post inoculation and 7 and 21 days post inoculation [DPI]) were amplified in triplicates over two independent quantitative polymerase chain reaction assays. The first technical replicate was performed 1 day after DNA extraction and the second 4 months later. Bars represent mean of three replicate and standard deviation values. greenhouse plants) in the quantification domain of the developed method.

Standard curves and qPCR optimization. V. inaequalis DNA serially diluted in host DNA (Table 2) was quantifiable from $0.1 \mathrm{pg}$ $\mu \mathrm{l}^{-1}$ to $1 \mathrm{ng} \mu \mathrm{l}^{-1}$. No influence of host DNA on pathogen DNA amplification was observed, and both amplifications gave comparable PCR efficiency (Wilcoxon Rank-Sum test; $P=0.3367$ ): 97.1 and $97.9 \%$ for the pathogen diluted in sterile distilled water and in host DNA, respectively. For $66 \%$ of the samples at a

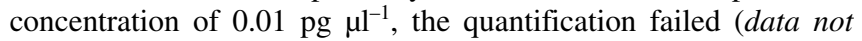
shown).

Malus $\times$ domestica DNA serially diluted in sterile distilled water

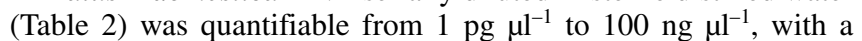
PCR efficiency of $97.3 \%$. No relevant differences (Kruskal-Wallis test; $P=0.4928$ ) of the PCR efficiencies due to different leaf ages were found (Table 2).

Change of the reported fluorescence $\left(\Delta \mathrm{R}_{\mathrm{N}}\right)$ during amplification was found to vary little over the entire tested concentration range for $\mathrm{ABC} 2$ primers. Thus, a concentration of $900 \mathrm{nM}$ was selected to ensure that primer amount was not a limiting factor during the reaction. The EF1 primers reported a higher $\Delta R_{N}$ with $600 \mathrm{nM}$ concentration. Lower $\mathrm{Ct}$ values were found at $250 \mathrm{nM}(\mathrm{Ct}=21.05$ $\pm 0.025)$ and $400 \mathrm{nM}(\mathrm{Ct}=21.23 \pm 0.08)$ probe concentrations for $\mathrm{ABC} 2$ and EF1, respectively.

Quantification by qPCR of $\mathrm{V}$. inaequalis in infected apple leaves. Colonization coefficients were highest for the susceptible Gala (Fig. 2). Three hours after inoculation, the colonization coefficient was not statistically different among the four tested cultivars (Kruskal-Wallis test; $P=0.0547)$. At $7 \mathrm{dpi}$, however, differences between cultivars were statistically significant (Kruskal-Wallis test; $P$ $=0.0286$ ), mainly due to fungal growth on Gala. At 21 dpi, differences between cultivars had increased (Kruskal-Wallis test; $P=$ 0.0227), with Gala and Milwa showing significantly more fungal growth than Discovery and Florina (Tukey-Kramer HSD test; $P<$ $0.05)$. After $35 \mathrm{dpi}$, the colonization coefficient of Milwa reached the maximal $\mathrm{CC}_{\text {corrected }}$ value of 0.0646 , showing an increase in fungal biomass of more than 26 times that at 3 hpi. In Gala, the colonization coefficient reached 0.8877 (i.e., an increase of more than 118 times that at 3 hpi and 13.7 times higher than Milwa during the same time period). Fungal growth between these two cultivars was significantly different (Tukey-Kramer HSD test; $P<$ 0.0001). On Discovery (a cultivar with quantitative and probably Rvil resistance genes) and Florina (Rvi6 and Rvil resistance genes), no fungal growth was observed. On the four cultivars tested during this experiment, symptoms were noted as highly sporulating lesions (class 4) on Gala whereas, on Milwa, symptoms varied between chlorosis with slight sporulation and necrotic spots (class

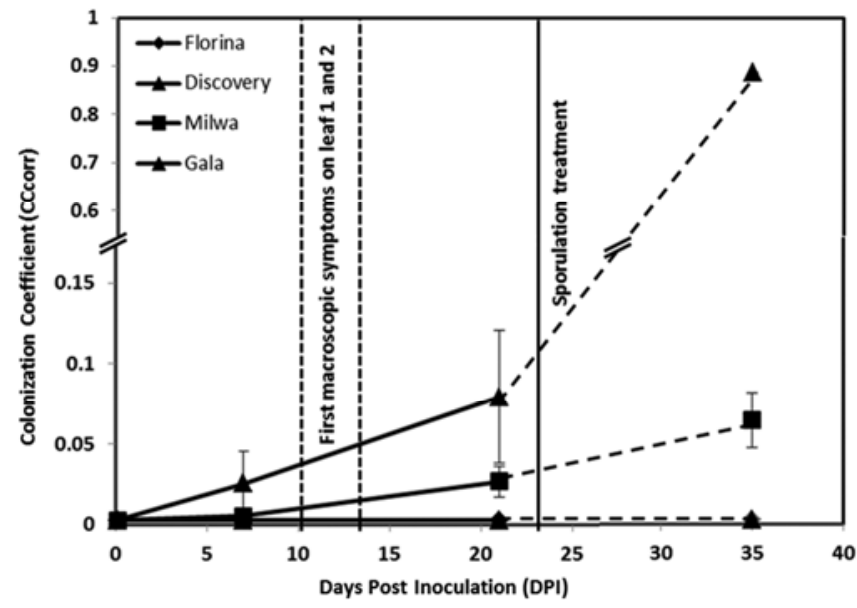

Fig. 2. Colonization coefficient $\left(\mathrm{CC}_{\text {corrected }}\right)$ calculated at different time points for the second leaf (L2) from the top of the shoot of 'Gala', 'Milwa', 'Discovery', and 'Florina' inoculated with field inoculum of Venturia inaequalis. Data points represent means of three replicates and bars represent standard deviation from the means. 
3a) on the first leaf and chlorosis (class 2) on leaf two and marginally on leaf three (data not shown). The first two inoculated leaves of Gala and Milwa developed similar macroscopic symptoms until 10 to 13 dpi. The symptoms between 13 and 17 dpi on the third leaf of Milwa were not consistent, ranging from class 0 to 2, while those on the same leaf of Gala always showed the same symptoms (i.e., class 4). Discovery and Florina did not show any symptoms (class 0 ) over the time frame of the experiment.

In the second experiment (Fig. 3), the effect of ontogenic resistance of leaves was visible in Gala, with leaf number 5 allowing no fungal development (Kruskal-Wallis test; $P=$ 0.1032 ). Leaf number 3 showed a drastically reduced colonization coefficient at 14 and 21 dpi compared to leaf 1 , which showed an 18-fold increase in pathogen biomass during the 21 days of the experiment. In this cultivar, differences in $\mathrm{CC}_{\text {corrected }}$ values between leaves were not significantly different 3 hpi (Kruskal-Wallis test; $P=0.9565$ ) and 4 dpi (Kruskal-Wallis test; $P=0.2881)$. At $7 \mathrm{dpi}$, the differences in $\mathrm{CC}_{\text {corrected }}$ between leaves 1,3 , and 5 were almost significant (Kruskal-Wallis test; $P$ $=0.0608$ ). Significant differences were found at 14 dpi (KruskalWallis test; $P=0.0273$ ) and at $21 \mathrm{dpi}$ (Kruskal-Wallis test; $P=$ 0.0439 ). These differences in fungal growth were found between leaf 1 and leaf 5, with intermediate values for the leaf 3. Florina

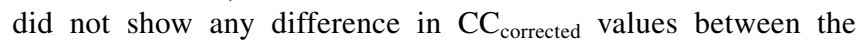
three examined leaves at any time point. Differences between the two cultivars were highly significant (Wilcoxon Rank-Sum test; $P<0.0001)$.

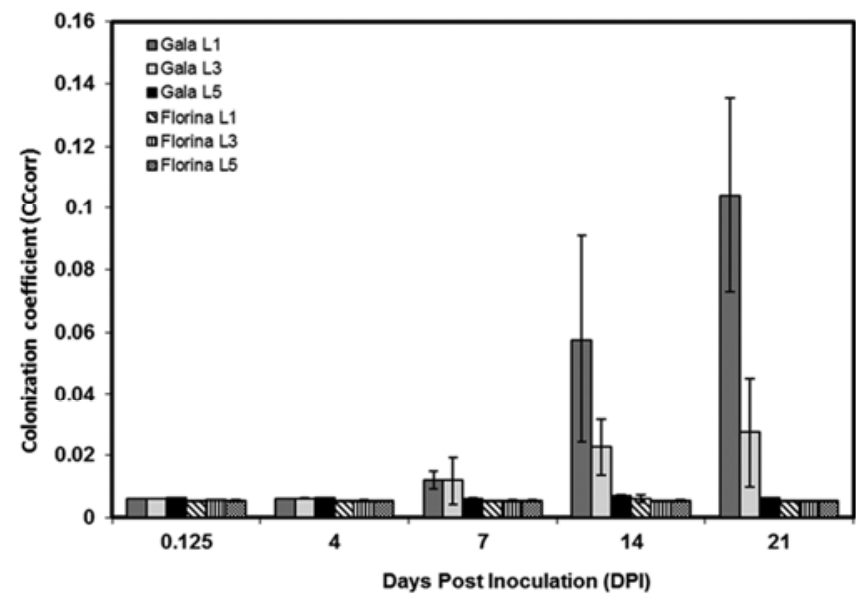

Fig. 3. Colonization coefficient $\left(\mathrm{CC}_{\text {corrected }}\right)$ calculated at different time points for leaf one ( $L 1$, youngest unfurled and expanding leaf), leaf 3 (L3), and leaf 5 (L5) of 'Gala' and 'Florina' highly susceptible and highly resistant cultivars, respectively, inoculated with field inoculum of Venturia inaequalis. Data points represents means of three replicates and bars represent standard deviation from the means.
The colonization coefficient determined after symptoms development on the $F_{1}$ progeny of the cross of Gala $\times$ Dülmener Rosenapfel reflected well the visual classification of the progeny individuals because the differences in $\mathrm{CC}_{\text {corrected }}$ values of the groups of individuals classified in the symptomatic class were highly significantly different with both single-spore isolates (Kruskal-Wallis test; $P<0.0001$ ). Differences were located between susceptible class 4 and resistant class 2 and between class 4 and $3 a$ with both fungal strains (Table 3 ). Moreover, the analysis of strain 1066 showed statistically significant differences between class $3 b$ and 2 and between class $3 a$ and 2. Some overlap was present between class $3 b$ with 4 and between class $3 b$ and $3 a$ for both singlespore isolates (Table 3). In the analysis of leaves inoculated with the EU-NL24 strain, it was not possible to calculate the colonization coefficient for 3 of 37 samples due to failure in apple DNA amplification.

In the fourth experiment, the $\mathrm{CC}_{\text {corrected }}$ was assessed in the progeny Gala $\times$ Durello di Forlì at $10 \mathrm{dpi}$, before symptoms were visible. Then, at $21 \mathrm{dpi}$, symptoms were scored. Similarly to the experiment with the progeny of Gala $\times$ Dülmener Rosenapfel, molecular quantification correlated with visual scoring data and highly significant statistical differences were found between the visual scoring classes (Kruskal-Wallis test; $P<0.0001$ ). Differences were located between highly susceptible (class 4 ) and both resistant classes 2 and 0 . However, in this experiment, it was not possible to differentiate neighboring classes (e.g., between class 4 and $3 b$, between class $3 \mathrm{~b}$ and $3 \mathrm{a}$, or between class $3 \mathrm{a}$ and 2; Table 3 ).

\section{Discussion}

Precise identification, detection, and quantification of pathogen in plant tissues are becoming important steps in plant pathology research. Moreover, a scorer-independent quantitative diagnostic of a large sample number is desirable. In the present work, we report the development and application, according to the main recommendation of the Minimum Information for publication of Quantitative Real-Time PCR Experiments guidelines (7), of a real-time qPCR for the quantification of $V$. inaequalis in artificially infected Malus $\times$ domestica leaves.

Results of visual scoring and qPCR were comparable but, compared with the conventional disease scoring used today to screen plant materials of breeding programs, the developed molecular method showed clear advantages, the most important being the detection and quantification of the pathogen in asymptomatic apple leaves, the objectivity of observations, and its predictive potential.

The methodology used in this study followed basically the same step-by-step process used by Valsesia et al. (42) to quantify Plasmopara viticola in artificially infected Vitis vinifera leaves.

The standard curve-based method presented in this study enabled the quantification of the pathogen in host tissues using a multiplex assay. Amplification and quantification of the pathogen

Table 3. Colonization coefficient $\left(\mathrm{CC}_{\text {corrected }} \log\right.$ transformed) calculated for two $\mathrm{F}_{1}$ seedlings populations: 'Gala $\times$ Dülmener Rosenapfel' inoculated with two single-spore isolates (EU-NL24 and 1066) and 'Gala $\times$ Durello di Forlì' inoculated with field inoculum of Venturia inaequalis

\begin{tabular}{|c|c|c|c|c|c|c|}
\hline \multirow[b]{4}{*}{ Severity classes $^{\mathrm{z}}$} & \multicolumn{6}{|c|}{ Plant material, inoculum used ${ }^{y}$} \\
\hline & \multicolumn{4}{|c|}{ Gala $\times$ Dülmener Rosenapfel progeny } & \multirow{2}{*}{\multicolumn{2}{|c|}{$\begin{array}{c}\text { Gala } \times \text { Durello di Forlì progeny } \\
\text { Field inoculum }\end{array}$}} \\
\hline & \multicolumn{2}{|c|}{ EU-NL24 } & \multicolumn{2}{|c|}{1066} & & \\
\hline & $\mathrm{CC}(\log ) \pm \mathrm{SD}$ & $N$ & $\mathrm{CC}(\log ) \pm \mathrm{SD}$ & $N$ & $\mathrm{CC}(\log ) \pm \mathrm{SD}$ & $N$ \\
\hline 0 & & $\ldots$ & $\ldots$ & $\ldots$ & $-2.17 \pm 0.001 b$ & 10 \\
\hline 2 & $-0.64 \pm 0.34 b$ & 6 & $0.47 \pm 0.08 \mathrm{c}$ & 23 & $-2.13 \pm 0.05 b$ & 26 \\
\hline $3 \mathrm{a}$ & $-0.59 \pm 0.14 b$ & 5 & $-0.15 \pm 0.14 b$ & 9 & $-1.99 \pm 0.32 \mathrm{ab}$ & 4 \\
\hline $3 b$ & $-0.08 \pm 0.18 \mathrm{ab}$ & 5 & $-0.74 \pm 0.24 \mathrm{ab}$ & 3 & $-1.82 \pm 0.50 \mathrm{ab}$ & 4 \\
\hline 4 & $0.57 \pm 0.67 \mathrm{a}$ & 18 & $-1.58 \pm 0.17 \mathrm{a}$ & 6 & $-1.69 \pm 0.45 \mathrm{a}$ & 14 \\
\hline
\end{tabular}

${ }^{y}$ Progenies of Gala $\times$ Dülmener Rosenapfel and Gala $\times$ Durello di Forlì were used to calculate the colonization coefficient after and before symptoms development, respectively. EU-NL24 and 1066 single-spore isolates were used to chamber inoculate seedlings of Gala $\times$ Dülmener Rosenapfel progeny, as defined by Bus et al. (4), and field inoculum mix was used to spray inoculate seedlings of Gala $\times$ Durello di Forlì progeny. Means colonization coefficient $\left(\mathrm{CC}_{\text {corrected }}\right) \log$ transformed \pm standard deviation $(\mathrm{SD})$. Values not connected by the same letter are significantly different (Tukey-Kramer honestly significant difference test, $P<0.05)$. $N=$ number of observations.

${ }^{\mathrm{z}}$ Visual scoring classes as defined by Chevalier et al. (11). 
was possible starting from $0.5 \mathrm{pg}$ of genomic DNA per reaction $\left(0.1{\left.\mathrm{pg} \mathrm{l}^{-1}\right)}\right.$ (Table 2). This result was in the same range of quantification limit found in other studies $(42,44)$.

Results of the infection performed on the same leaf with the two single-spore isolates showed differences (in some cases statistically assured) of the two fungal isolates between severity classes. These dissimilarities were attributed to differences in avirulence pattern of the two strains (Table 3): EU-NL24 isolate showed a high number of seedlings with highly sporulating lesions (class 4) whereas, with the 1066 isolate, chlorosis lesions (class 2) were the most abundant. Differences were no more statistically significant for the weak resistant (class 3a) and weak susceptible (class 3b) seedlings. Thus, the experiment with two different pathogen strains showed the potential of the developed methodology in disentangling the virulence pattern of different pathogen strains.

The qPCR analysis of the $F_{1}$ progenies after symptoms development could be helpful to give a numerical value to samples and, consequently, an objective evaluation of lesions. The analysis, before symptoms development, showed that it was possible to differentiate samples between highly susceptible and highly resistant seedlings (Table 3). However, it was not possible to differentiate samples in intermediate classes. The reason could be explained by (i) analysis of a population with minor resistance genes leading to a gradient between symptomatic classes and (ii) sampling before symptom development would be limited by the nonhomogeneous inoculation, so that partial sampling of a leaf with a leaf borer instead of taking the entire leaf may underestimate the presence of the fungus if the sampling point does not coincide with the infection point. The colonization coefficient calculated before symptom development (Table 3 ) on this $\mathrm{F}_{1}$ progeny was a good predictor for the symptomatic classes for 50 of 60 seedlings.

Data of multiplex reactions obtained from the real-time PCR device are expressed as $\mathrm{Ct}$ values for host and pathogen. Many methods of calculation can be found in the literature to analyze the $\mathrm{Ct}$ values given by qPCR analysis. Livak and Schmittgen (25) developed the $2^{-\Delta \Delta \mathrm{Ct}}$ method, assuming comparable (approximately $100 \%)$ PCR efficiency for both host and pathogen, and Pfaffl (32) developed a calculation based on the $2^{-\Delta \Delta \mathrm{Ct}}$ method taking into account different PCR efficiencies between different organisms. These two methods, however, have been developed primarily for gene expression analysis. Another interesting method has been developed (42), the infection coefficient (IC). This method is based on the ratio between $\mathrm{Ct}$ values of both organisms (IC = $\left.\mathrm{Ct}_{\text {host }} / \mathrm{Ct}_{\text {pathogen }}\right)$. Lately, Mideros et al. (28) also reported the calculation of an IC which, however, was not a ratio of the pathogen and host $\mathrm{Ct}$ values but a ratio of DNA concentrations. However, the IC value calculated by Valsesia et al.(42) over different dilution series, always with the same proportion between the two organisms (Malus DNA and Venturia DNA) was not constant, suggesting a different degree of infection of the host tissues. Because of this missing linear relationship between $\mathrm{Ct}$ values and DNA amount, it was decided to develop the colonization coefficient and to use it instead of the IC. By using DNA concentration as a substitute of the $\mathrm{Ct}$ value, the colonization coefficient for the same sample dilutions remained highly constant (data not shown). With this kind of calculation, assuming comparable DNA extraction efficiency between host and pathogen, factors leading to different DNA extraction efficiencies (e.g., differences in reagent volumes and re-precipitation procedures) could be avoided.

An advantage of the developed methodology is the quantification of the total pathogen biomass in host tissues. Leaves showing no sporulation but having a high mycelium biomass may give a similar colonization coefficient of leaves with high sporulation and low mycelial biomass. In the studied pathosystem, both situations could have a significant impact on the epidemic and disease management of apple scab disease: (i) high sporulating leaf would increase secondary infections by spreading conidia on the same plant or on neighboring plants and (ii) high subcuticular mycelial biomass could increase pathogen amount in leaf litter material in autumn and, therefore, increase the primary inoculum the following spring. Both situations would be detectable with the proposed method.

Two limits of the quantification procedure described in this work have been identified. First, it could be that differences in extraction efficiencies between conidia and the mycelium present in or on the freeze-dried leaf material may be present. Due to the lack of data in the literature, it was assumed that they were comparable. Second, from some samples clearly showing heavy sporulation typical for class 4 , it was not possible to amplify host DNA. In these cases, high concentrations of pathogen were detected (up to $4 \mathrm{ng}$ $\left.\mu \mathrm{l}^{-1}\right)$ but no or only a limited amount host DNA $\left(<0.2 \mathrm{ng} \mu \mathrm{l}^{-1}\right)$. This problem was observed only with a few highly susceptible seedlings and after the sporulation treatment (35 dpi). Analyses of the pictures of the Gala $\times$ Dülmener Rosenapfel cross taken before lesion scoring showed relevant necrotic tissues on samples where host DNA amplification failed. In these cases, failure in host amplification was probably due to degraded host DNA in necrotic lesions present in highly susceptible leaves after a prolonged period of infection. Apple DNA amplification failure was not observed for the seedlings inoculated with strain 1066 and analysis of the pictures did not show relevant necrotic lesions of leaves inoculated with this pathogen strain.

The correction coefficient $(\triangle \mathrm{CC})$ used for normalization procedure during $\mathrm{CC}_{\text {corrected }}$ calculation has been judged as being unessential because statistical analysis of the variance did not differ with or without this factor (data not shown). However, at the beginning of the experiment ( $3 \mathrm{hpi}$ ) in susceptible cultivars and for all sampling points for the resistant cultivars, $97 \%$ of the final $\mathrm{CC}_{\text {corrected }}$ values were due to $\triangle \mathrm{CC}$ contribution. In the last sampling point, in susceptible tissues of the susceptible cultivar, $96 \%$ of the final $\mathrm{CC}_{\text {corrected }}$ values were due to fungal growth, therefore coming from the $\mathrm{CC}$ values before correction. Thus, the different contribution of the $\triangle \mathrm{CC}$ between initial and final sampling points was not negligible.

In conclusion, this method could be useful to give a numerical value to lesions in apple breeding programs. Other possible applications of the developed qPCR methodology could be the assessment of fungicide and biocontrol efficacy, pathogenicity test, test with detached leaves where leaves may deteriorate before visual scoring can be unequivocally made, and quantification of the pathogen's pressure in autumn to make a correlation with the amount of primary inoculum present the spring after. This could lead to the avoidance of a laborious analysis such as the Potential Ascospore Dose (PAD) used to quantify the overwintering ascospores per square meter and predict the beginning of an apple scab epidemic in commercial orchards (14). Field sampling for PAD estimation with qPCR may be onerous $(9,10)$ not only in terms of number of samples needed, time for collection, extraction of DNA, and processing of samples but also in terms of costs (the analysis of 96 samples costs around US\$110). To lower analysis costs, some strategies such as sample bulking may facilitate this task. However, the number of qPCR analyses and the action threshold should be carefully evaluated experimentally in the field, in different climatic conditions, and with different apple cultivars. Moreover, in marker-assisted breeding programs, DNA could be extracted during the latent period of the infection and used, first, to determine the presence or absence of the DNA markers and, second, to quantitatively screen $V$. inaequalis on the seedlings. Finally, the method could be helpful to quantify pathogen pressure in the presence of asymptomatic-ontogenic resistant leaves, allowing precise control measures in autumn (sanitation and eradicant fungicides) or in spring (protectant fungicides), depending on the pathogen pressure in a precise orchard condition.

\section{Acknowledgments}

We thank the EnviroChange project of the Autonomous Province of Trento, Italy for funding this research; M. Kellerhals of the Swiss Federal Research Station Agroscope ACW Wädenswil for supplying V. inaequalis inoculum; V. Bus from Plant and Food Research (New Zealand) for providing stains EUNL24 and 1066 and assistance during the inoculation of the segregating popula- 
tion Gala $\times$ Dülmener Rosenapfel; G. Valsesia for providing North American field isolates from her master's thesis; and K. von Arx and F. Keller for assistance during part of the project.

\section{Literature Cited}

1. Allen, G. C., Flores-Vergara, M. A., Krasnyanski, S., Kumar, S., and Thompson, W. F. 2006. A modified protocol for rapid DNA isolation from plant tissues using cetyltrimethylammonium bromide. Nat. Protocols $1: 2320-2325$.

2. Bénaouf, G., and Parisi, L. 1998. Characterization of Venturia inaequalis pathogenicity on leaf discs of apple trees. Eur. J. Plant Pathol. 104:785-793.

3. Böhm, J., Hahn, A., Schubert, R., Bahnweg, G., Adler, N., Nechwatal, J., Oehlmann, R., and Osswald, W. 1999. Real-time quantitative PCR: DNA determination in isolated spores of the mycorrhizal fungus Glomus mosseae and monitoring of Phytophthora infestans and Phytophthora citricola in their respective host plants. J. Phytopathol. (Berlin) 147:409-416.

4. Bus, V. G. M., Laurens, F. N. D., van de Weg, W. E., Rusholme, R. L., Rikkerink, E. H. A., Gardiner, S. E., Bassett, H. C. M., Kodde, L. P., and Plummer, K. M. 2005. The Vh8 locus of a new gene-for-gene interaction between Venturia inaequalis and the wild apple Malus sieversii is closely linked to the Vh2 locus in Malus pumila R12740-7A. New Phytol. 166:1035-1049.

5. Bus, V. G. M., Rikkerink, E. H. A., Caffier, V., Durel, C. E., and Plummer, K. M. 2011. Revision of the nomenclature of the differential host-pathogen interaction of Venturia inaequalis and Malus. Annu. Rev. Phytopathol. 49:391-413.

6. Bus, V. G. M., Rikkerink, E. H. A., van de Weg, W. E., Rusholme, R. L., Gardiner, S. E., Bassett, H. C. M., Kodde, L. P., Parisi, L., Laurens, F. N. D., Meulenbroek, E. J., and Plummer, K. M. 2005. The Vh2 and Vh4 scab resistance genes in two differential hosts derived from Russian apple R12740-7A map to the same linkage group of apple. Mol. Breed. 15:103116

7. Bustin, S. A., Benes, V., Garson, J. A., Hellemans, J., Huggett, J., Kubista, M., Mueller, R., Nolan, T., Pfaffl, M. W., Shipley, G. L., Vandesompele, J., and Wittwer, C. T. 2009. The MIQE Guidelines: minimum information for publication of quantitative real-time PCR experiments. Clin. Chem. 55:611622

8. Calenge, F., Faure, A., Goerre, M., Gebhardt, C., Van de Weg, W. E., Parisi, L., and Durel, C. E. 2004. Quantitative trait loci (QTL) analysis reveals both broad-spectrum and isolate-specific QTL for scab resistance in an apple progeny challenged with eight isolates of Venturia inaequalis. Phytopathology 94:370-379.

9. Carisse, O., and Jobin, T. 2012. Managing summer apple scab epidemics using leaf scab incidence threshold values for fungicide sprays. Crop Prot. 35:36-40

10. Carisse, O., Meloche, C., Boivin, G., and Jobin, T. 2009. Action threshold for summer fungicide sprays and sequential classification of apple scab incidence. Plant Dis. 93:490-498.

11. Chevalier, M., Lespinasse, Y., and Renaudin, S. 1991. A microscopic study of the different classes of symptoms coded by the $V f$ gene in apple for resistance to scab (Venturia inaequalis). Plant Pathol. 40:249-256.

12. Croxall, H. E., Gwynne, D. C., and Jenkins, J. E. E. 1952. The rapid assessment of apple scab on leaves. Plant Pathol. 1:39-41.

13. Didelot, F., Brun, L., and Parisi, L. 2007. Effects of cultivar mixtures on scab control in apple orchards. Plant Pathol. 56:1014-1022.

14. Gadoury, D. M., and MacHardy, W. E. 1986. Forecasting ascospore dose of Venturia inaequalis in commercial apple orchards. Phytopathology 76:112118.

15. Gessler, C., Patocchi, A., Sansavini, S., Tartarini, S., and Gianfranceschi, L. 2006. Venturia inaequalis resistance in apple. Crit. Rev. Plant Sci. 25:473503.

16. Gessler, C., and Stumm, D. 1984. Infection and stroma formation by Venturia inaequalis on apple leaves with different degrees of susceptibility to scab. J. Phytopathol. (Berlin) 110:119-126.

17. Gomez, C., Brun, L., Chauffour, D., and De Le Vallée, D. 2007. Effect of leaf litter management on scab development in an organic apple orchard. Agric. Ecosyst. Environ. 118:249-255.

18. Higuchi, R., Fockler, C., Dollinger, G., and Watson, R. 1993. Kinetic PCR analysis: real-time monitoring of DNA amplification reactions. Nat. Biotechnol. 11:1026-1030.

19. Holb, I. J., Heijne, B., and Jeger, M. J. 2003. Summer epidemics of apple scab: the relationship between measurements and their implication for the development of predictive models and threshold levels under different disease control regimes. J. Phytopathol. (Berlin) 151:335-343.
20. Keitt, G. W., and Jones, L. K. 1926. Studies of the epidemiology and control of apple scab. Agric. Exp. Stn. Univ. Wisc. Res. Bull. 73.

21. Kellerhals, M., and Furrer, B. 1994. Approaches for breeding apples with durable disease resistance. Euphytica 77:31-35.

22. Kollar, A. 1996. Evidence for loss of ontogenetic resistance of apple leaves against Venturia inaequalis. Eur. J. Plant Pathol. 102:773-778.

23. Li, B., and $\mathrm{Xu}, \mathrm{X}$. 2002. Infection and development of apple scab (Venturia inaequalis) in old leaves. J. Phytopathol. (Berlin) 150:687-691.

24. Lindhagen, M. 1996. Model analysis of leaf unfolding rate in Malus domestica Borkh. Sci. Hortic. 67:65-78.

25. Livak, K. J., and Schmittgen, T. D. 2001. Analysis of relative gene expression data using real-time quantitative PCR and the $2^{-\mathrm{DDCT}}$ method. Methods 25:402-408.

26. MacHardy, W. E. 1996. Fungicide uses in apple scab control: traditional roles. Pages 398-411 in: Apple Scab Biology, Epidemiology, and Management. American Phytopathological Society, St. Paul, MN

27. MacHardy, W. E. 1996. Ontogenic resistance to scab in Malus. Pages 104116 in: Apple Scab Biology, Epidemiology, and Management. American Phytopathological Society, St. Paul, MN.

28. Mideros, S. X., Windham, G. L., Williams, W. P., and Nelson, R. J. 2009. Aspergillus flavus biomass in maize estimated by quantitative real-time polymerase chain reaction is strongly correlated with aflatoxin concentration. Plant Dis. 93:1163-1170.

29. Parisi, L., Fouillet, V., Schouten, H. J., Groenwold, D., Didelot, F., Evans, K., Fischer, C., Gennari, F., Kemp, H., Lateur, M., Patocchi, A., Thissen, J., and Tsipouridis, C. 2004. Variability of the pathogenicity of Venturia inaequalis in Europe. Acta Hortic. 663:107-113.

30. Parisi, L., Lespinasse, Y., Guillaumes, J., and Krüger, J. 1993. A new race of Venturia inaequalis virulent to apples with resistance due to the $V f$ gene. Phytopathology 83:533-537.

31. Patocchi, A., Frei, A., Frey, J. E., and Kellerhals, M. 2009. Towards improvement of marker assisted selection of apple scab resistant cultivars: Venturia inaequalis virulence surveys and standardization of molecula marker alleles associated with resistance genes. Mol. Breed. 24:337-347.

32. Pfaffl, M. W. 2001. A new mathematical model for relative quantification in real-time RT-PCR. Nucleic Acids Res. 29:2002-2007.

33. Rasmussen, R. 2001. Quantification on the LightCycler. Pages 21-34 in: Rapid Cycle Real-Time PCR, Methods and Applications. S. Meuer, C. Wittwer, and K. Nakagawara, eds. Springer Press, Heidelberg, Germany.

34. Rozen, S., and Skaletsky, H. J. 2000. Primer3 on the WWW for genera users and for biologist programs. Pages 365-386 in: Bioinformatics Methods and Protocols: Methods in Molecular Biology. S. Krawetz and S. Misene, eds. Humana Press, Totowa, NJ.

35. Schena, L., Nigro, F., Ippolito, A., and Gallitelli, D. 2004. Real-time quantitative PCR: a new technology to detect and study phytopathogenic and antagonistic fungi. Eur. J. Plant Pathol. 110:893-908.

36. Schwabe, W. F. S. 1979. Change in scab susceptibility of apple leaves as influenced by age. Phytophylactica 11:53-56.

37. Soufflet-Freslon, V., Gianfranceschi, L., Patocchi, A., and Durel, C. E. 2008. Inheritance studies of apple scab resistance and identification of Rvi14, a new major gene that acts together with other broad-spectrum QTL. Genome 51:657-667.

38. Tartarini, S., Gennari, F., Pratesi, D., Palazzetti, C., Sansavini, S., Parisi, L. Fouillet, A., Fouillet, V., and Durel, C. E. 2004. Characterization and genetic mapping of major scab resistance genes from the old Italian apple cultivar 'Durello di Forlì'. Acta Hortic. 663:129-133.

39. Tenzer, I., and Gessler, C. 1997. Subdivision and genetic structure of four populations of Venturia inaequalis in Switzerland. Eur. J. Plant Pathol. 103:565-571.

40. Tenzer, I., and Gessler, C. 1999. Genetic diversity of Venturia inaequalis across Europe. Eur. J. Plant Pathol. 105:545-552.

41. Valsangiacomo, C., and Gessler, C. 1988. Role of the cuticular membrane in ontogenic and $V f$-resistance of apple leaves against Venturia inaequalis. Phytopathology 78:1066-1069.

42. Valsesia, G., Gobbin, D., Patocchi, A., Vecchione, A., Pertot, I., and Gessler, C. 2005. Development of a high-throughput method for quantification of Plasmopara viticola DNA in grapevine leaves by means of quantitative real-time polymerase chain reaction. Phytopathology 95:672-678.

43. Vandemark, G. J., and Barker, B. M. 2003. Quantifying Phytophthora medicaginis in susceptible and resistant alfalfa with a real-time fluorescent PCR assay. J. Phytopathol. (Berlin) 151:577-583.

44. Winton, L. M., Stone, J. K., Watrud, L. S., and Hansen, E. M. 2002. Simultaneous one-tube quantification of host and pathogen DNA with realtime polymerase chain reaction. Phytopathology 92:112-116. 